\title{
Nuclear Pore Complex Protein Nup93
}

National Cancer Institute

\section{Source}

National Cancer Institute. Nuclear Pore Complex Protein Nup93. NCI Thesaurus. Code C150286.

Nuclear pore complex protein Nup93 (819 aa, $93 \mathrm{kDa}$ ) is encoded by the human NUP93 gene. This protein is involved in nuclear pore functions. 